\title{
AGRICULTURE AND SCIENCE COLLABORATION: THE CASE OF ŁÓDŹ VOIVODESHIP (POLAND)
}

Marta Baraniak, PhD (ORCID: 0000-0002-6186-9514)

- University of Lodz, Faculty of Management

Correspondence address:

Matejki Street 22/26, 90-237, Łódź, Poland

e-mail: marta.baraniak@uni.lodz.pl

ABSTRACT: The article aims to evaluate the cooperation of Polish farmers from ŁódźVoivodeship with science and other farmers in the field of implementing innovation in farms. Paper and Pencil Interview (PAPI) method was used. The analysis covers150 Polish farms located in the Łódź Voivodeship. The farms for the study were selected from the Polish FADN (Farm Accountancy Data Network) sample. The study was made in 2018. The conducted research has proved that interest in scientific achievements depends on the innovativeness of farms. The cooperation between Polish farmers from Łódź Voivodeship in the field of innovation activity does not differ in terms of their farming type. A consequence of the farms' selection is the lack of the ability to generalise the results to the entire population of farms in the Łódź Voivodeship. The added value of the analysis is the presentation of the results in terms of farm innovation.

KEYWORDS: agricultural innovation, farms, farms and science collaboration 


\section{Introduction}

A much higher risk of failure characterises the innovation activities undertaken by the farmer than in other sectors of the economy. Farms can implement several types of innovations, including product and process. The innovative process is extremely complicated and time-consuming. Implementing innovations for most farmers relies on their knowledge and experience of other holdings, which may prove to be insufficient innovation activity and condemned to failure.

For this reason, supporting farmers in this area seems essential and necessary. Furthermore, foreign studies show that farms cannot just be passive participants while implementing innovations but must stimulate the activity of research and development related to innovation activities. In this dimension, agricultural innovation systems are already in operation, aiming to connect a number of factors related to the implementation of innovation, such as farmers, R\&D institutions, universities, agricultural advisory services, non-governmental organisations, and the financial system. Proper cooperation of these entities and the active participation of innovative farmers in the processes can significantly affect a higher degree of commercialisation through/by using the obtained research results.

The article aims to evaluate the cooperation of Polish farmers from Łódź Voivodeship with science and other farmers in the field of implementing innovation in farms.

The analyses were prepared based on questionnaire interviews (PAPI method) conducted in 2018 in the Łódź Voivodeship in Poland. The farms for the study were selected from the Polish FADN sample. These entities voluntarily keep accounting and provide this information to the FADN.

\section{An overview of the literature}

Innovation is extremely popular and applies to every economic sector, including agriculture. Thematic popularity also translates into scientific publications. However, researching the field of innovation in agriculture is additionally hindered. The specificity of the activity and the lack of a universal tool for measuring the innovativeness of farms results in the lack of published data that could be used to assess it. The possible reason for this is the lack of a clear definition that would indicate what could be classified as agricultural innovation (Läpple et al., 2015, p. 2) and the fact that innovation, in general, is a phenomenon difficult to measure due to its complexity (OECD, 2010, p. 30). 
The factors determining the implementation of innovations by farmers that appear in the literature were divided into two groups of variables: structural (related to the farm and innovation activity) and behavioural (features directly related to the farm manager). Economic size is one of the most frequently mentioned structural variables conditioning the implementation of innovation in agriculture. The authors emphasise that farmers with larger farms are more likely to innovate (Diederen et al., 2002; Deuninck et al., 2008; van der Meulen et al., 2016). Besides, farms with crop production implement innovations more often than other types of agricultural entities (van der Meulen et al., 2016). There is some doubt about farm debt as some authors state that households with higher indebtedness can implement innovations earlier using the incurred debt (von Pischke, 1978; Diederen et al., 2002). However, some studies have not positively verified this hypothesis (Lipton, 1976; Blank \& Weber, 1994). In addition to these essential factors, the implementation of innovation is also conditioned by such variables as solvency (Diederen et al., 2002; Läpple et al., 2015), the number of people on the farm (Läpple et al., 2015), market position (Diederen et al., 2002), net value-added, family farm income, operating subsidies, assets, cash flow (van der Meulen et al., 2016).

In the group of behavioural variables, the farmer's age should be highlighted, which most often appears in models of farm innovation. The authors state that a senior farmer is less willing to implement innovation (Diederen et al., 2002). It is related to lower education and, thus, a lack of skills to assess innovation possibilities. Older farmers may also have a shorter time horizon and be less willing to invest in new technologies. Also, the implementation of innovations is conditioned by behavioural variables such as off-farm work, marriage, agricultural education (Läpple et al., 2015).

Unfortunately, most of the works mentioned above omit an essential factor that condition the implementation of innovation, namely the cooperation of farmers with science. The successful diffusion of innovation is not possible without cooperation. Current researches on innovation collaboration between sectors focus mainly on the manufacturing industry (Liu et al., 2019; Lalic et al., 2016; Broekel \& Boschma, 2012) and the high-tech industry (Mikhaylov et al., 2018, Hong et al., 2014, Liefner \& Hennemann,2011; Li et al., 2011). However, agriculture is ignored in these studies.

The lack of research on cooperation in agriculture does not mean that it is absent or there is no need for it. Cooperation in climate change and the growing trend towards organic food has helped farmers realise their vision of agriculture. This applies to, among others sharing know-how in organic farming methods, promoting a seed bank, encouraging farm education systems, or reducing fossil energy consumption (Lutz et al., 2017, pp. 934-935). 
Cooperation allows for better results to be achieved than through an individual project. The strengths of one group can compensate for the limitations of the other (Hoffmann et al., 2007, p. 355). Countries such as Sweden and Denmark have accumulated experience in this field since the 19th century (Moraru, 2018; Böök \& Johansson, 1988; Lantbrucarnas Riksförbund and Swedish Cooperative Centre, 1980). In Poland, the Agricultural Advisory Center started operating only in 2005, and one of its priorities is building a knowledge transfer network for innovation.

Cooperation in agriculture can have a diverse nature. However, in this work, the author would like to draw attention to its two basic types: farmers with science and farmers with farmers. Each has its advantages, and their combination can guarantee success in implementing innovation and sustainable development of a farm.

Farmers' cooperation with science requires a full understanding of each group's knowledge, skills, and limitations. Research projects are often implemented with limited contact between scientists and farmers, which can result in misunderstandings. As a result, communication and interaction between the two groups remain superficial (Hoffmann et al., 2007, p. 356). Despite many adversities, there are many examples of successful cooperation between scientists and farmers. One such example is a pioneering initiative to regenerate cultivated biodiversity as a result of cooperation between French farmers, facilitators, and scientists (Berthet et al., 2020).

Another example is the Indian selection of the most appropriate crop and plant density based on climate forecasts (Meinke et al., 2013). Regarding forecasts, mention should be made of SARRA-h, a crop monitoring system that uses rainfall forecasts to assess the probable sorghum yield in Burkina Faso (Mishra et al., 2008). Understanding farmers is extremely important in the cooperation of farmers and scientists. The speed of establishing cooperation can greatly reduce the effects of climate change. The method of establishing contact is significant in this respect. A Colombian team of researchers explored a way of establishing a dialogue between scientists and farmers that would give farmers opportunities in the face of short- and long-term climate change. They used for its Local Technical Agro-Climatic Committees (LTACs) in two Colombian regions (Loboguerrero et al., 2018). Searching for dialogue methods is important because farmers consider it riskier to introduce innovations from socially distant external entities than those developed by farmers (Hoffmann et al., 2007, p. 359).

Studies have shown that cooperation with other farms is very important for farmers. According to them, cooperation means reducing costs and labour and increasing the value of know-how (Lutz et al., 2017). Farmers prefer cooperation between farms rather than science because they have the same 
problems as a social group. Conducting the same activity, they understand its specificity. Thanks to this, they can share their solutions and ideas. Informal cooperation has been and will be important among farmers, especially for small farms (Lutz et al., 2017, p. 926). This applies not only to shared machine parks and know-how but also to mutual assistance in fieldwork, especially during the harvest season (Cialdella et al., 2009, p.133). However, nowadays, formal cooperation groups between farmers are increasingly important. One of the most frequently mentioned countries in the field of cooperative agricultural relations in the Netherlands. Environmental Cooperatives have been in operation there since the 1990s - EC (Riley et al., 2018). Their main advantage is strengthening the voice of farmers when implementing new projects. Similar formalised farmers' cooperation groups operate, among others in Germany (Prager \& Vanclay, 2010) and in Great Britain (Franks et al., 2007).

Many studies indicate that cooperation between farmers brings measurable benefits, especially in the context of environmental protection (Siebert et al., 2006, Soini \& Aakkula, 2007). However, this cooperation will not always be possible. The degree of development of entities is a big limitation. For example, organic and conventional farmers will not agree on the common meaning of 'good farming' about agricultural production and environmental protection (Slovenc, 2019, p. 125). Besides, in their work, Riley et al. (2018) showed that the relationships between farmers are not universal and differ depending on the type of business. Farmers also often have conflicts with their neighbours, including personal misunderstandings that have been identified as barriers to participation in formal groups (Franks et al., 2016).

In Poland, formal operational groups began to operate only as part of the EU funding perspective for 2014-2020. They operate based on The Agricultural European Innovation Partnership (EIP-AGRI). The Network for Innovation in Agriculture and Rural Areas (SIR) helps build these groups. In addition to farmers, advisors, entrepreneurs, innovation brokers, and NGOs, the network also includes the Ministry of Agriculture and Rural Development, state research institutes, and universities, as well as local governments (SIR,2020). The diversity of network participants ensures the correct interaction within operational groups, resulting in the development of innovative projects that can be implemented in practice.

When implementing innovations, collaboration is important at every stage of this process. Undoubtedly, in times of climate change, the importance of cooperation increases. Therefore, all agricultural stakeholders must cooperate in implementing climate-smart agriculture practices (Kilungu \& Meadu, 2014). 


\section{Research methods}

Concerning the work purpose, as well as to the arguments collected based on reading the cited research papers, the following hypotheses were formulated:

$\mathrm{H} 1:$ Interest in learning achievements depends on the innovativeness of farms from Łódź Voivodeship.

H2: The cooperation of farmers and farmers from Łódź Voivodeship varies depending on the type of business.

Empirical research was conducted on a sample of farms sharing their accounting data as part of the Farm Accountancy Data Network (FADN). Polish FADN is the only institution that collects sensitive farm data. The set of agricultural entities keeping accounts under the Polish FADN in 2018 included 12,032 farms of natural persons and 188 farms of legal persons. The total number of 12,220 entities is a statistically representative sample in terms of agricultural type and economic size class, as well as the FADN region for the Polish FADN observation field numbering 730,883 commercial farms in Poland (Floriańczyk et al., 2019, p. 44). Participation in FADN is voluntary, and therefore farms may opt-out of accounting after only one year. Failure to continue recording income and costs makes it difficult to compare and analyse results. Unfortunately, FADN is the only institution that regularly collects farm financial data. The thematic scope of the database does not apply to both innovation and R\&D activities. However, the Polish FADN helps conduct individual surveys on a sample of accounting farms.

Questionnaire interviews were conducted at the end of 2017 and 2018 using the PAPI method. The analysed farms operate in the Łódź Voivodeship. The selection of objects for the study was purposeful within the economic size of the farms. The entities were selected for examination by the Institute of Agricultural and Food Economics - National Research Institute. In 2018, 880 farms participated in the FADN agricultural accounting system in the Łódź Voivodeship, of which 390 are the smallest entities with an economical size below 25,000 euros, and 490 - farms with a size exceeding 25,000 euros (Polski FADN, 2020). Research works covered farms with a crop, livestock, and mixed production profile. Farms with an economic size of fewer than 25,000 euros were rejected. This is because they are generally social entities that show low levels of investment and debt. Thus, the final sample selected for the study included 490 farms.

Questionnaire interviews using PAPI method were possible thanks to the support of the advisory service of the Łódź Agricultural Advisory Centre in Bratoszewice. This assistance was necessary due to legal restrictions on access to data and information security. 
In order to carry out the study, an interview questionnaire was used, containing mainly closed questions (31) and a small number of open questions (5). The questionnaire was divided into three substantive parts:

- Part I - Characteristics of a farm;

- Part II - Innovative potential of a farm;

- Part III - Financing the innovative activity of a farm.

After the interviews, 150 correctly completed questionnaires were received, covering $30.6 \%$ of selected entities.

In developing the study results, appropriate computer programs were used, including PS Imago 5.1, as well as Microsoft Office (with particular emphasis on Word and Excel).The implementation of the goal and the verification of hypotheses was possible thanks to the use of the following statistical measures: structure indices, mean, median, standard deviation, coefficient of variation and V-Cramer's coefficient.

Due to the term research design (2016-2017), all concepts related to innovation were taken from the Oslo Manual 2005. Thus, innovation is understood as "the implementation of a new or significantly improved product (good or service), or process, a new marketing method, or a new organisational method in business practices, workplace organisation or external relations" (OECD, 2005). The author is aware of the current version of the manual (OECD, 2018). However, when the concept of the study was developed and conducted, it had not yet been published. Therefore it is justified to cite the Oslo Manual 2005 methodology (mainly in terms of defining innovation).

\section{Results of the research}

Entities conducting mixed activity predominate among the surveyed individual farms (46.3\%). This is the most popular type of activity among entities with an economic size of no more than 100,000 euros (medium-small and medium-large).

Table 1. Type of individual farms by economic size class (in \%)

\begin{tabular}{|c|c|c|c|c|}
\hline \multirow{2}{*}{ Type of individual farms } & \multicolumn{3}{|c|}{ Economic size class of individual farms } & \multirow{2}{*}{ Total } \\
\hline & medium-small & medium-large & large and larger & \\
\hline crop & 17.2 & 20.0 & 33.3 & 20.8 \\
\hline livestock & 24.1 & 38.6 & 38.1 & 32.9 \\
\hline mixed & 58.6 & 41.4 & 28.6 & 46.3 \\
\hline Total & 100.0 & 100.0 & 100.0 & 100.0 \\
\hline
\end{tabular}

Source: own study based on the interviews conducted. 
In contrast, the greatest part of large and larger farms (with an economical size exceeding 100,000 euros) conducts livestock production (table 1).

$57.3 \%$ of analysed farms introduced at least one innovation in 20162018 (table 2). It should be noted that medium-sized entities are characterised by the highest activity in this area (50 $000<$ euros $<100$ 000). The smallest farms happened to be the least innovative.

Table 2. Innovativeness of individual farms by economic size class (in \%)

\begin{tabular}{lllll}
\hline \multirow{2}{*}{ Innovativeness of farms } & \multicolumn{2}{l}{ Economic size class of individual farms } & Total \\
\cline { 2 - 4 } & medium-small & medium-large & large and larger & \\
\hline $\begin{array}{l}\text { farms that have not } \\
\text { implemented innovation }\end{array}$ & 60.3 & 31.4 & 31.8 & 42.7 \\
\hline innovative farms & 39.7 & 68.6 & 68.2 & 57.3 \\
\hline Total & 100.0 & 100.0 & 100.0 & 100.0 \\
\hline
\end{tabular}

Source: own study based on the interviews conducted.

Farmers most often implemented process innovations at the farm level. $88.4 \%$ of innovative farms conducted this kind of activity. $21.2 \%$ of product innovations were implemented at the local market level (in the Łódź Voivodeship). However, only $3 \%$ of product innovations are new in the country (table 3 ).

Table 3. Range of implemented product and process innovations (in \%)

\begin{tabular}{llll}
\hline \multirow{2}{*}{ Range of innovations } & \multicolumn{2}{l}{ Type of innovation } & Total \\
\cline { 2 - 3 } & product & process & \\
\hline at farm level & 75.8 & 88.4 & 84.3 \\
\hline at local market level & 21.2 & 11.6 & 14.7 \\
\hline at domestic market level & 3.0 & 0.0 & 0.0 \\
\hline Total & 100.0 & 100.0 & 100.0 \\
\hline
\end{tabular}

Source: own study based on the interviews conducted.

When analysing innovation, the expenditure on this type of activity should not be forgotten. In this work, the ratio of expenditure to income from a farm (FADN data from 2016) is understood as an innovation degree. Table 4 presents the basic parameters of the indicator for all economic values of the analysed entities. On average, $24.2 \%$ of income are spent by large and larger farms annually on implementing innovation. However, this group is characterised by a huge diversity, indicated by the high standard deviation and 
a coefficient of $80.2 \%$. The smaller the entities, the smaller the expenditure on innovation activities.

Table 4. Degree of innovativeness of individual farms by economic size class (in \%)

\begin{tabular}{lllll}
\hline \multirow{2}{*}{ Parameters } & \multicolumn{3}{l}{ Economic size class of individual farms } & Total \\
\cline { 2 - 4 } & medium-small & medium-large & large and larger & \\
\hline & 19.3 & 22.8 & 24.2 & 22.1 \\
\hline $\mathrm{Me}$ & 15.0 & 20.0 & 19.5 & 20.0 \\
\hline $\mathrm{S}(\mathrm{x})$ & 15.2 & 12.5 & 19.4 & 14.5 \\
\hline $\mathrm{VS}(\mathrm{x})$ & 78.8 & 54.8 & 80.2 & 65.6 \\
\hline
\end{tabular}

- mean, Me - median, $\mathrm{S}(\mathrm{x})$ - standard deviation, VS(x) - coefficient of variation.

Source: own study based on the interviews conducted.

A high degree of innovation makes it possible to analyse the cooperation of farmers with scientists and with other farmers. Respondents were asked if they were interested in the learning achievements in the field of conducting an activity that could contribute to the development of the farm. The vast majority $(82.0 \%)$ answered in the affirmative. Interestingly, farms that have already implemented innovations show the greatest interest (table 5). The V-Cramer coefficient has confirmed the relationship between innovation and interest in science. This relationship is weak but statistically significant $(\mathrm{V}=0.272 ; \mathrm{p}=0.002)$.

Table 5. Interest in learning achievements by the innovativeness of individual farms (in \%)

\begin{tabular}{|c|c|c|c|}
\hline \multirow[b]{2}{*}{$\begin{array}{l}\text { Are you interested in learning achievements in } \\
\text { the field of your business that could contribute } \\
\text { to the development of the farm? }\end{array}$} & \multicolumn{2}{|c|}{ Innovativeness of individual farms } & \multirow[b]{2}{*}{ Total } \\
\hline & $\begin{array}{l}\text { farms that have } \\
\text { not implemented } \\
\text { innovation }\end{array}$ & innovative farms & \\
\hline Yes & 70.3 & 90.7 & 82.0 \\
\hline No & 3.1 & 2.3 & 2.7 \\
\hline I have no opinion & 26.6 & 7.0 & 15.3 \\
\hline Total & 100.0 & 100.0 & 100.0 \\
\hline
\end{tabular}

Source: own study based on the interviews conducted.

$84.9 \%$ of innovative farms also believe that there is a need for cooperation between farmers and scientists. Over $4.7 \%$ of entities that have not implemented innovation do not see such a need (table 6). 
Table 6. The need for farmers to cooperate with scientists by the innovativeness of individual farms (in \%)

\begin{tabular}{|c|c|c|c|}
\hline \multirow{2}{*}{$\begin{array}{l}\text { Do you think there is a need for farmers to } \\
\text { cooperate with scientists from universities and } \\
\text { research institutes? }\end{array}$} & \multicolumn{2}{|c|}{ Innovativeness of individual farms } & \multirow[b]{2}{*}{ Total } \\
\hline & $\begin{array}{l}\text { farms that have } \\
\text { not implemented } \\
\text { innovation }\end{array}$ & innovative farms & \\
\hline Yes & 73.4 & 84.9 & 80.0 \\
\hline No & 4.7 & 2.3 & 3.3 \\
\hline I have no opinion & 21.9 & 12.8 & 16.7 \\
\hline Total & 100.0 & 100.0 & 100.0 \\
\hline
\end{tabular}

Source: own study based on the interviews conducted.

The literature review has already noted that farmers' cooperation with science can bring several benefits. According to respondents, the most important is "the possibility of solving specific problems on the farm". $40.0 \%$ of non-innovative farms and $31.3 \%$ of innovative entities gave such an answer. As a second benefit, respondents describe "the possibility of reducing costs". However, this benefit is more important for innovative farms (26.6\%).

Table 7. Benefits in cooperation between farmers and scientists by the innovativeness of individual farms (in \%)

\begin{tabular}{|c|c|c|c|}
\hline \multirow[b]{2}{*}{$\begin{array}{l}\text { What benefits do you see in the possible } \\
\text { cooperation between farmers and scientists? }\end{array}$} & \multicolumn{2}{|c|}{ Innovativeness of individual farms } & \multirow[b]{2}{*}{ Total } \\
\hline & $\begin{array}{l}\text { farms that have } \\
\text { not implemented } \\
\text { innovation }\end{array}$ & innovative farms & \\
\hline $\begin{array}{l}\text { The possibility of solving specific problems } \\
\text { on the farm }\end{array}$ & 40.0 & 31.3 & 35.1 \\
\hline The possibility of reducing costs & 18.0 & 26.6 & 22.8 \\
\hline Increase of farm competitiveness & 16.0 & 9.4 & 12.3 \\
\hline $\begin{array}{l}\text { Increased financial support in the field } \\
\text { of implemented innovations }\end{array}$ & 8.0 & 10.9 & 9.6 \\
\hline Access to the latest knowledge & 10.0 & 9.4 & 9.6 \\
\hline Opportunity to develop & 4.0 & 12.5 & 8.8 \\
\hline A sense of prestige & 4.0 & 0.0 & 1.8 \\
\hline Total & 100.0 & 100.0 & 100.0 \\
\hline
\end{tabular}

Source: own study based on the interviews conducted. 
Less significant is the "increase in farm competitiveness" and "increased financial support in the field of implemented innovations". $20.2 \%$ of all respondents see "access to the latest knowledge" (9.6\%), "opportunity to develop" (8.8\%) and "a sense of prestige" (1.8\%) in cooperation with science (table 7).

Farmers were also asked if there was a need to cooperate with other farmers as part of their innovation activities. More than $70 \%$ of respondents answered in the affirmative, of which $72.1 \%$ of innovative farms (table 8). Interestingly, this kind of cooperation is less desirable than cooperation with science.

Table 8. The need for farmers to cooperate with farmers by the innovativeness of individual farms (in \%)

\begin{tabular}{|c|c|c|c|}
\hline \multirow{2}{*}{$\begin{array}{l}\text { Do you think there is a need for farmers to } \\
\text { cooperate with farmers as part of their innova- } \\
\text { tion activities? }\end{array}$} & \multicolumn{2}{|c|}{ Innovativeness of individual farms } & \multirow[b]{2}{*}{ Total } \\
\hline & $\begin{array}{l}\text { farms that have } \\
\text { not implemented } \\
\text { innovation }\end{array}$ & innovative farms & \\
\hline Yes & 69.8 & 72.1 & 71.1 \\
\hline No & 9.5 & 3.5 & 6.0 \\
\hline I have no opinion & 20.6 & 24.4 & 22.8 \\
\hline Total & 100.0 & 100.0 & 100.0 \\
\hline
\end{tabular}

Source: own study based on the interviews conducted.

It is known that farmers constantly undertake all kinds of cooperation. Almost $48 \%$ of farms that have not implemented innovations assess the current cooperation as "good". A similar assessment was given by almost $50 \%$ of innovative entities (table 9).

Table 9. Assessment of cooperation with other farmers by the innovativeness of individual farms (in \%)

\begin{tabular}{|c|c|c|c|}
\hline \multirow[b]{2}{*}{$\begin{array}{l}\text { How do you assess the current cooperation } \\
\text { with other farmers in the region? }\end{array}$} & \multicolumn{2}{|c|}{ Innovativeness of individual farms } & \multirow[b]{2}{*}{ Total } \\
\hline & $\begin{array}{l}\text { farms that have } \\
\text { not implemented } \\
\text { innovation }\end{array}$ & innovative farms & \\
\hline good & 47.6 & 49.4 & 48.6 \\
\hline sufficient & 42.9 & 42.4 & 42.6 \\
\hline irrelevant / no cooperation & 9.5 & 8.2 & 8.8 \\
\hline Total & 100.0 & 100.0 & 100.0 \\
\hline
\end{tabular}

Source: own study based on the interviews conducted. 
It was decided to also present the obtained results in a cross-section of the type of conducted activity. However, no significant differences between the analysed groups were noticed. The current cooperation is assessed most favourably by $58.1 \%$ of crop entities. $10.4 \%$ of livestock farms and almost $12 \%$ of mixed entities estimate cooperation as "irrelevant" or even "no cooperation". No crop farmer gave such an answer (table 10). Also, the relationship between the assessment of cooperation with other farmers and the type of business activity, measured by the V-Cramer coefficient, is very weak and statistically insignificant $(\mathrm{V}=0.124 ; \mathrm{p}=0.345)$.

Table 10. Assessment of cooperation with other farmers by type of individual farms (in \%)

\begin{tabular}{lllll}
\hline \multirow{2}{*}{$\begin{array}{l}\text { How do you assess the current cooperation } \\
\text { with other farmers in the region? }\end{array}$} & \multicolumn{3}{l}{ Type of individual farms } & \multirow{2}{*}{ Total } \\
\cline { 2 - 4 } & crop & livestock & mixed & \\
\hline good & 58.1 & 43.8 & 47.1 & 48.3 \\
\hline sufficient & 41.9 & 45.8 & 41.2 & 42.9 \\
\hline irrelevant / no cooperation & 0.0 & 10.4 & 11.8 & 8.8 \\
\hline Total & 100.0 & 100.0 & 100.0 & 100.0 \\
\hline
\end{tabular}

Source: own study based on the interviews conducted.

The performed statistical analysis allows for the verification of the formulated hypotheses. Therefore, there is no reason to reject the H1 hypothesis. Based on the analysis of the V-Cramer coefficient, it should be stated that in the researched group of farmers, the interest in scientific achievements depends on the innovativeness of farms. Thus, entities that have already implemented innovations express a greater willingness to learn about new developments in the field of science. Such a strong need for farmers to cooperate with science may result from its deficit in reality. Thus, it may be that Polish farmers from Łódź Voivodeship are not afraid of contact with scientists, as claimed by Hoffman et al. in their work (Hoffmann et al., 2007, p. 359). On the contrary, Polish farmers expect support in solving specific farm problems or reducing costs.

The H2 hypothesis concerns cooperation between farmers from Łódź Voivodeship. However, as it was rejected, it cannot be concluded that the relations between farmers differ depending on the activities conducted. The results of the analyses undertaken, therefore, contradict Riley's et al. (2018) statements. Additionally, it should be noted that the relations between Polish farmers are not as negative as described by Franks et al. (2016). Most respondents assessed the current cooperation with other farmers as "good" or "sufficient". Only less than $9 \%$ of respondents do not cooperate or think it is 
"irrelevant". It can, therefore, be concluded, like Lutz et al. (2017), that cooperation with other farmers is important for the respondents and helps (although still slightly) in implementing innovative activities.

The conducted analyses introduced some novelty to the discussion on cooperation in the agricultural sector. Presenting the results in the crosssection of innovation allows for the estimation of the impact of cooperation on the implementation of innovation in agriculture. The author realises that the differences are not spectacular, but it can be noticed that innovative farms are characterised by a greater need for cooperation with science and farmers. They also see other benefits in cooperation. There is no doubt that this is due to the experience gained. However, based on the results obtained, it can already be seen that cooperation certainly positively affects the development of innovation in farms.

\section{Conclusions}

The development of innovation in farms is an unquestionable necessity these days. It allows for more efficient and effective production methods while respecting the principles of environmental protection. There is no doubt that the introduction of advanced technologies requires cooperation in the entire complex innovation process. The article deals with the problem of cooperation between Polish farmers and science and other farmers. It allows the assessment of its current state and the formulation of preliminary recommendations. Data on the state of innovation also increases the work's value in agricultural entities due to the lack of such information by entities collecting statistical data. The conducted research allows us to conclude that Polish farmers need cooperation with science because it will allow them to develop specific benefits. Undoubtedly, cooperation between agriculture and science in Poland is still in its infancy. The operational groups are a very good introduction to its development. Institutional solid support at a local level is needed, with significant support from agricultural advisory services. The Ministry of Agriculture and Rural Development should intensify marketing related to the creation of operational groups. European funds under the measure "Cooperation" give farmers several benefits, but they are not always sufficiently informed.

The empirical research conducted in this paper allowed for the formulation of a number of useful conclusions, which are, however, limited. A consequence of the selection of farms from the Polish FADN sample is the lack of the ability to generalise the results to the entire population of farms in the Łódź Voivodeship. Moreover, in this analysis, only the largest farms were used to increase the probability of a majority share of innovative entities in 
the group of respondents. Therefore, the actual distribution of innovative farms in all economic size classes is unknown. Moreover, it should be remembered that the study selected only agricultural entities that keep accounts. This procedure was dictated by the possibility of conducting questionnaire interviews and the access to quantitative data.

Bearing in mind further research, the analysed group of farms should be expanded to include the smallest entities, the economic size of which does not reach 25,000 euros. However, most of all, further research should focus on a detailed analysis of the impact of cooperation between farmers and science on the level of innovation. Not only structural but also behavioural factors must be taken into account.

\section{References}

Berthet, E. T., Bosshardt, S., Malicet-Chebbah, L., Frank, G. V., Weil, B., Segrestin, B., Goldringer, I., 2020. Designing innovative management for cultivated biodiversity: lessons from a pioneering collaboration between french farmers, facilitators and researchers around participatory bread wheat breeding. Sustainability, 12(2), 605, doi:10.3390/su12020605.

Blank, S. C., \& Weber, S. 1994. Financing agriculture in California's new risk environment: Proceedings of a conference on December 1, 1993, in Sacramento, California. Davis, CA: Agricultural Issues Center, University of California.

Böök, S. A., \& Johansson, T., 1988. The co-operative movement in Sweden: past, present - the future. Stockholm: Swedish Soc. for Co-operative Studies.

Broekel, T., \& Boschma, R., 2012. Knowledge networks in the Dutch aviation industry: the proximity paradox. Journal of Economic Geography, 12(2), 409-433, doi:10. 1093/jeg/lbr010.

Cialdella, N., Dobremez, L., \& Madelrieux, S., 2009. Livestock farming systems in urban mountain regions. Outlook on Agriculture, 38(2), 127-135, doi:10.5367/000000 009788632412

Deuninck, J., Carels, K., Van Gijseghem, D., \& Piessens, I., 2008. Innovatie in land- en tuinbouw in Vlaanderen: resultaten van het Landbouwmonitoringsnetwerk [Innovation in agriculture and horticulture in Flanders: Results of the Agricultural Monitoring Network] (Rep.). Brussels, Belgium: Department Landbouw en Visserij.

Diederen, P., Wolters, A., \& Van Meijl, H., 2002. Innovation and farm performance: the case of Dutch agriculture. In A. Kleinknecht \& P. Mohnen (Eds.), Innovation and firm performance: econometric explorations of survey data (pp. 73-85), London, United Kingdom: Palgrave MacMillan.

Floriańczyk, Z., Osuch, D., \& Płonka, R., 2019. Wyniki Standardowe 2018 uzyskane przez gospodarstwa rolne uczestniczące w Polskim FADN: Część I. Wyniki Standardowe, Warszawa, Polska: Polski FADN.

Franks, J. R., Emery, S., Whittingham, M., \& McKenzie, A., 2016. Farmer attitudes to cross-holding agri-environment schemes and their implications for Countryside Stewardship. International Journal of Agricultural Management, 5(4), 78-95, doi:10.5836/ijam/2016-05-78. 
Franks, J., \& Gloin, A. M., 2007. Environmental co-operatives as instruments for delivering across-farm environmental and rural policy objectives: Lessons for the UK. Journal of Rural Studies, 23(4), 472-489, doi:10.1016/j.jrurstud.2007.03.002.

Hoffmann, V., Probst, K., \& Christinck, A., 2007. Farmers and researchers: how can collaborative advantages be created in participatory research and technology development? Agriculture and Human Values, 24(3), 355-368, doi:10.1007/ s10460-007-9072-2.

Hong, J., Yu, W., Guo, X., \& Zhao, D., 2014. Creative industries agglomeration, regional innovation and productivity growth in China. Chinese Geographical Science, 24(2), 258-268, doi:10.1007/s11769-013-0617-6.

Kilungu, S., \& Meadu, V., 2014. Helping farmers catch their dreams, even as the climate changes,https://ccafs.cgiar.org/blog/helping-farmers-catch-their-dreamseven-climate-changes [01-07-2020].

Lalic, B., Tasic, N., Marjanovic, U., Delic, M., \& Cvetkovic, N., 2016. Inter-organisational collaboration for innovation in manufacturing firms. Proceedings of the 27th International DAAAM Symposium 2016 DAAAM Proceedings, 0721-0729, doi:10.2507/27th.daaam.proceedings.104.

Lantbrucarnas Riksförbund and Swedish Cooperative Centre, 1980. Farmers' cooperation in Sweden: origins and development, Stockholm: Lts. Förlag.

Läpple, D., Renwick, A., \& Thorne, F., 2015. Measuring and understanding the drivers of agricultural innovation: Evidence from Ireland. Food Policy, 51, 1-8, doi:10. 1016/j.foodpol.2014.11.003.

Li, E., Li, X., \& Liu, Z., 2011. Relationships and evolving networks of rural manufacturing clusters: a case study in Yucheng County, Henan Province of China. Chinese Geographical Science, 21(3), 364-376, doi:10.1007/s11769-011-0449-1.

Liefner, I., \& Hennemann, S., 2011. Structural holes and new dimensions of distance: the spatial configuration of the Scientific Knowledge Network of China's optical technology sector. Environment and Planning A: Economy and Space, 43(4), 810829, doi:10.1068/a43100.

Lipton, M., 1976. Agricultural finance and rural credit in poor countries. World Development, 4(7), 543-553. doi:10.1016/0305-750x(76)90065-6.

Liu, B., Xu, W., Liu, J., Yao, B., Zhou, Z., \& Pham, D. T., 2019. Human-robot collaboration for Disassembly Line Balancing Problem in remanufacturing. Volume 1: Additive Manufacturing; Manufacturing Equipment and Systems; Bio and Sustainable Manufacturing, doi:10.1115/msec2019-2919.

Loboguerrero, A. M., Boshell, F., León, G., Martinez-Baron, D., Giraldo, D., Mejía, L. R., Cock, J., 2018. Bridging the gap between climate science and farmers in Colombia. Climate Risk Management, 22, 67-81, doi:10.1016/j.crm.2018.08.001.

Lutz, J., Smetschka, B., \& Grima, N., 2017. Farmer cooperation as a means for creating local food systems - Potentials and Challenges. Sustainability, 9(6), 925, doi:10. 3390/su9060925.

Meinke, H., Howden, S. M., Baethgen, W., Hammer, G. L., Selvaraju, R., \& Stone, R. C., 2013. Can climate knowledge lead to better rural policies and risk management practices? NOAA Workshop: Insights and Tools for Adaptation: Learning from Climate Variability, Washington.

Mikhaylov, S. J., Esteve, M., \& Campion, A., 2018. Artificial intelligence for the public sector: opportunities and challenges of cross-sector collaboration. Philosophical Transactions of the Royal Society A: Mathematical, Physical and Engineering Sciences, 376(2128), 20170357, doi:10.1098/rsta.2017.0357. 
Mishra, A., Hansen, J. W., Dingkuhn, M., Baron, C., Traoré, S. B., Ndiaye, O., \& Ward, M. N., 2008. Sorghum yield prediction from seasonal rainfall forecasts in Burkina Faso. Agricultural and Forest Meteorology, 148(11), 1798-1814, doi:10.1016/j. agrformet.2008.06.007.

Moraru, R., 2018. The cooperative system from Sweden agriculture: main features and evolution. Lucrări Ştiinţifice, Seria Agronomie, 61(1), 43-48.

OECD, 2005. Guidelines for collecting and interpreting technological innovation data: Oslo manual. Paris, France.

OECD, 2010. The OECD innovation strategy: getting a head start on tomorrow. Paris, France.

OECD, 2018. Oslo manual: Guidelines for collecting, reporting and using data on innovation. Paris, France: OECD Publishing.

Polski FADN, Szeregi czasowe, https://fadn.pl/publikacje/szeregi-czasowe/ [03-072020].

Prager, K., \& Vanclay, F., 2010. Landcare in Australia and Germany: comparing structures and policies for community engagement in natural resource management. Ecological Management \& Restoration,11(3), 187-193, doi:10.1111/j.1442-8903. 2010.00548.x.

Riley, M., Sangster, H., Smith, H., Chiverrell, R., \& Boyle, J., 2018. Will farmers work together for conservation? The potential limits of farmers' cooperation in agrienvironment measures. Land Use Policy, 70, 635-646, doi:10.1016/j.landusepol.2017.10.049.

Siebert, R., Toogood, M., \& Knierim, A., 2006. Factors affecting European farmers' participation in biodiversity policies. Sociologia Ruralis, 46(4), 318-340, doi:10. 1111/j.1467-9523.2006.00420.x.

SIR, 0 SIR, https://sir.cdr.gov.pl/o-sir/ [02-07-2020].

Slovenc, M., 2019. Can a "good farmer" and a "bad farmer" cooperate?: An examination of conventional and organic farmers' perceptions of production and environmental protection. In A. A. Lukšič, \& T. Tkalec (Eds.), Intertwining of Diverse Minds in(to) Political Ecology (pp. 111-129). Ljubljana, Slovenia: Inštitut Časopis za kritiko znanosti.

Soini, K., \& Aakkula, J., 2007. Framing the biodiversity of agricultural landscape: The essence of local conceptions and constructions. Land Use Policy, 24(2), 311-321, doi:10.1016/j.landusepol.2006.03.001.

Van der Meulen, H., Van Asseldonk, M., \& Ge, L., 2016. Adoption of innovation in European agriculture (Rep.). FLINT Deliverable.

Von Pischke, J. D., 1978. When is a smallholder credit necessary? Development Digest, 16(3), 6-14. 